\title{
STRATEGI PENCITRAAN PERUSAHAAN AGRIBISNIS MELALUI MEDIA VIRTUAL
}

\author{
Brand Image Strategy on Agribussines Coporation by Virtual Media \\ Rinaldy Yusuf ${ }^{*}$ dan Ninuk Purnaningsih \\ Departemen Sains Komunikasi dan Pengembangan Masyarakat, Fakultas Ekologi Manusia, IPB \\ *) Email :yusufrinaldy@gmail.com
}

Diterima 14 Februari 2010 / Disetujui 25 November 2010

\begin{abstract}
This study is about the effectiveness of agribusiness corporate brand image strategy which doing by PT. Plantera on virtual media and related factors. This study use quantitative approach with survey method and supported by qualitative data. Respondent is people who already visited Plantera Fruit Paradise Ngebruk's fan page on Facebook and then decided to came to the Plantera. This study focused on relation between respondent's social economic characteristics (gender, age, level education, and level income), public perception about the corporate, and corporate brand image strategy on Facebook Fan Page with the effectiveness itself. Based on result, from four social economic characteristics on respondent (gender, age, level education, level income) only level education, level income, and age of respondent that have relation with the effectiveness of corporate brand image strategy on Facebook Fan Page.. The conclusion of this study is the corporate brand image strategy which doing by PT. Plantera is well done and had an effective result on it's implementation.
\end{abstract}

Keywords: Brand Image, Facebook Fan Page, Agribusiness

\section{PENDAHULUAN}

\section{Latar Belakang}

Di Indonesia, pengguna media virtual pun kian hari kian bertambah banyak. Menurut data tahun 2009 , Indonesia kini menempati peringkat kelima di Asia dengan jumlah pengguna media virtual sebanyak 25 Juta orang. Sebagian besar di antaranya merupakan penggerak jejaring sosial seperti Facebook yang termasuk kelompok generasi muda terdidik (well-educated). Pengguna Facebook di Indonesia menurut data statistik tahun 2009 , termasuk dalam rangking tujuh besar jumlah pengguna Facebook di seluruh dunia dengan pengguna aktif mencapai 5.949.740 pengguna. Bentuk penggunaan media virtual yang mulai banyak dilakukan oleh kalangan bisnis saat ini yaitu strategi pencitraan melalui Fan Page Facebook atau Laman Penggemar Facebook (LPF). LPF memiliki sejumlah kelebihan di antaranya adalah kemudahan akses karena sebagian besar pengguna media virtual di Indonesia memiliki akun Facebook. Update dan berbagi informasi (foto, berita, dan video) juga dapat dilakukan dengan lebih cepat dan mudah. Artinya, perusahaan dapat dengan mudah mempromosikan dan menciptakan citra perusahaan secara lebih efektif dan lebih murah. Meski demikian, perusahaan harus tetap mewaspadai sisi negatif yang muncul. Seperti halnya citra positif yang mudah dan cepat terwujud, citra negatif juga dapat terjadi dengan cepat dan mudah. Informasi yang negatif tentang perusahaan dapat tersebar sama cepat dan sama luas jangkauannya.
Salah satu perusahaan agribisnis yang berlokasi di Jawa Tengah yaitu PT. Plantera, sejak 2008 juga telah menggunakan media virtual ini (LPF). PT. Plantera memanfaatkan secara intensif LPF yang dikelolanya di laman "Plantera Fruit Paradise Ngebruk" untuk mempromosikan produk andalannya yaitu, Plantera Fruit Paradise. Plantera Fruit Paradise yang dikelola PT. Plantera merupakan kebun buah terbesar pertama di Jawa Tengah. Kebun buah yang dibuka pada akhir tahun 2008 ini menempati lahan seluas 210 hektar yang dahulunya adalah lahan yang ditanami cengkeh. Oleh karena terbilang masih baru, maka mutlak dilakukan strategi promosi dan publikasi yang efektif. Pihak manajemen Plantera kemudian merasa media virtual yang satu ini cukup efektif untuk menyampaikan pesan-pesan dari Plantera kepada massa/publik sasaran Plantera secara massal dan instan. Sebelumnya promosi dilakukan melalui media massa dan media elektronik namun biaya dan keefektifannya tidak sebanding dengan dana yang dikucurkan untuk strategi tersebut. Sementara pencitraan melalui LPF lebih mudah dan lebih murah.

Penggunaan LPF merupakan cara yang dapat dikatakan masih baru dan masih jarang dilakukan dalam strategi promosi barang atau jasa serta strategi pencitraan sebuah perusahaan di dunia maya. Selama ini, promosi dilakukan melalui virtual banner, ad space atau memasang hyperlink web di beberapa situs. Namun, cara ini dianggap kurang efektif karena kurang menyentuh massa dalam jumlah banyak dan kurang interaktif. Lalu, penggunaan LPF mulai dilirik sebagai saluran atau media 
bagi perusahaan yang ingin mempromosikan produknya baik jasa maupun barang atau sebagai media interaksi dengan konsumennya. Akan tetapi, langkah penggunaan LPF sebagai media promosi dan pencitraan Plantera dan pembangunan pertanian di Indonesia pada umumnya, sepatutnya perlu diperhitungkan. Tidak hanya perusahaan-perusahaan besar, namun petani dan koperasikoperasi pertanian dapat menerapkan strategi tersebut pada promosi dan pencitraan produk atau organisasi mereka. Mengacu pada alasan yang telah disebutkan di atas maka strategi pencitraan melalui media virtual (LPF) yang dilakukan Plantera untuk promosi kebun agrowisatanya, menjadi menarik dan perlu dikaji.

\section{Perumusan Masalah}

Masalah yang hendak dikaji dalam penelitian ini adalah bagaimana efektivitas strategi pencitraan perusahaan melalui LPF yang dilakukan oleh Plantera Fruit Paradise?

\section{Tujuan Penelitian}

Berdasarkan masalah penelitian di atas maka tujuan penelitian ini adalah menganalisis keefektifan strategi pencitraan perusahaan melalui media LPF yang dilakukan Plantera kepada publik eksternalnya.

\section{Kegunaan Penelitian}

Penelitian ini diharapkan dapat memberikan gambaran dan perbandingan mengenai strategi pencitraan melalui media massa maupun media virtual yang dilakukan oleh perusahaan. Penelitian ini juga dapat menjadi tambahan literatur penelitian mengenai strategi pencitraan perusahaan melalui media virtual terutama LPF bagi para akademisi dan peneliti. Selain itu, hasil penelitian ini diharapkan dapat menjadi bahan evaluasi dan pertimbangan bagi PT. Plantera, dalam perencanaan dan perbaikan strategi pencitraan perusahaan melalui media virtual kedepannya.

\section{PENDEKATAN TEORITIS}

\section{Tinjauan Pustaka}

\section{Strategi Public Relations (PR) dalam Membangun Citra Perusahaan}

Citra adalah seperangkat ide dan kesan seseorang terhadap suatu obyek tertentu. Sikap dan tindakan seseorang terhadap suatu obyek akan ditentukan oleh citra obyek tersebut yang menampilkan kondisi terbaiknya (Ruslan, 2003). Suatu perusahaan harus melakukan analisis citra (image analysis) dalam mengetahui sejauhmana peranan PR dalam perusahaan tersebut. Analisis citra tersebut terdiri dari analisis terhadap khalayak sasaran yang memerlukan penilaian (tanggapan), peserta/publik tentang citra perusahaan, citra program, pelayanan jasa, penampilan pemberian pelayanan, dan para pesaingnya. Power (2005) menyebutkan citra perusahaan adalah citra keseluruhan dari kesatuan dari citra merek produk (product brand image), citra merek perusahaan (corporate brand image) dan citra pemimpin perusahaan. Citra dapat berbentuk positif dan negatif. Citra positif dapat terbentuk apabila publik mendapatkan informasi yang baik mengenai suatu perusahaan dan begitu sebaliknya untuk citra negatif.
Ketika berkomunikasi dengan pihak eksternal (khalayak), PR memiliki strategi khusus dalam mencapai pembentukan citra positif sebagai sasaran perusahaan. PR dapat melakukan teleconference maupun press release atau menggunakan media. Masing-masing memiliki kelebihan dan kekurangan tersendiri. Hamidi (2007) menyebutkan komunikasi dapat dikatakan efektif bila pesan yang disampaikan dapat dipahami oleh komunikan, komunikan bersikap atau berperilaku seperti apa yang dikehendaki komunikator dan ada kesesuaian antarkomponen. Asumsi dalam teori tentang efektivitas pesan yaitu jika komunikasi diharapkan efektif maka pesanpesannya perlu dikemas sedemikian rupa sehingga sesuai atau merupakan kebutuhan komunikan, menarik perhatian, simbol yang mudah dipahami dan cara memperoleh yang mudah. Apabila PR memperhatikan hal tersebut maka bukan tidak mungkin citra positif perusahaan akan terbentuk di benak publik sasaran atau dengan kata lain strategi pencitraan dapat efektif.

Public Relations atau PR mengacu pada sebuah konsep yaitu proses komunikasi dua arah antara perusahaan dengan publiknya (internal maupun eksternal). Rumanti (2002) mengungkapkan PR adalah untuk menumbuhkan dan mengembangkan hubungan baik secara teratur antara organisasi dan publiknya. PR membantu manajemen dalam penyampaian informasi dan tanggap terhadap opini publik dan secara efektif memantau berbagai perubahan. Suhandang (2004) dalam Putri (2005) menyebutkan bahwa titik berat kegiatan PR adalah kepentingan dan kepercayaan publiknya. Effendy (1986) dalam Redjeki (2003) menyatakan bahwa PR memiliki tugas dan tanggung dan tanggung jawab membina hubungan dengan publik-publiknya, meliputi hubungan (dengan publik) internal (karyawan, pemegang saham dan pemasok) dan hubungan (dengan publik) eksternal (konsumen, pelanggan, komunitas, instansi pemerintah dan kalangan pers).

Menurut Rumanti (2002), fungsi utama PR adalah:(1) menumbuh dan mengembangkan hubungan baik antara organisasi/perusahaan dengan publiknya, baik internal maupun eksternal, (2) menanamkan pengertian, menumbuhkan motivasi, dan meningkatkan partisipasi publik, (3) menciptakan opini publik yang menguntungkan bagi organisasi/perusahaan dan publik. Publik terbagai menjadi dua macam (Muplihah, 2005), yaitu: (1) publik intern adalah publik yang menjadi bagian dari perusahaan itu sendiri. Misalnya: Karyawan, pimpinan, pemegang saham, dan sebagainya, (2) publik ekstern adalah orang luar/masyarakat umum yang perlu mendapat informasi dan penerangan demi tumbuhnya perasaan positif dan hubungan/kerjasama yang baik dari mereka.

Strategi PR terletak pada cara dan kebijakan dalam mendekati kelompok publik sehingga mereka terbuka untuk menerima pesan tersebut (Muplihah, 2005). Strategi menjadi penting karena memberikan fokus terhadap usaha yang dilakukan, yang dapat membantu untuk mendapatkan hasil serta melihat jauh ke depan. Rencana jangka panjang inilah yang menjadi pegangan bagi para praktisi PR untuk menyusun berbagai rencana teknis, dan langkah komunikasi yang akan diambil sehari-hari. Untuk 
dapat bertindak secara strategis, kegiatan PR harus menyatu dengan visi dan misi perusahaannya.

Empat hal yang harus diperhatikan oleh seorang praktisi PR menurut Rumanti (2002) adalah: (1) bahwa publik itu manusia, jadi mereka tidak pernah bebas dari berbagai pengaruh apa saja, (2) manusia itu cenderung suka memperhatikan, membaca atau mendengarkan pesan yang dirasakan sesuai dengan kebutuhan atau sikap mereka, (3) adanya berbagai media massa yang beragam, memberikan efek yang beragam pula bagi publiknya, (4) media massa memberikan efek dengan variasi yang besar kepada publik atau perseorangan maupun kelompok.

\section{Media Virtual}

Media virtual atau biasa disebut internet menurut Rozi (2009) adalah jaringan komputer dengan skala dunia. Sementara media virtual sebagai media komunikasi menurut Haque et. al (2006) adalah media persilangan (hybrid) yang dapat mengkombinasikan semua tiga strategi komunikasi yang ada yaitu komunikasi massa, komunikasi interpersonal dan komunikasi melalui perantaraan mesin (machine underactivity communication). Media virtual muncul pada penghujung abad 21 dan menjadi begitu diminati oleh masyarakat dunia. Sejumlah fasilitas yang diberikan oleh media virtual yaitu: browsing, berkirim surat elektronik (e-mail), berkomunikasi interaktif (chatting), transfer file, blogging, dan lainnya.

Menurut Sosiawan (2001), media virtual ternyata bukan sekedar menjadi alternatif media komunikasi saja, tetapi juga ikut membentuk pola-pola komunikasi baru. Bentuk atau pola komunikasi baru tersebut antara lain: sifat komunikasi bermedia berubah menjadi komunikasi yang interaktif, sifat komunikasi tidak lagi selalu synchronorous tetapi dapat pula bersifat asynchronorous, jarak ruang, waktu antara pengirim dan penerima pesan menjadi keniscayaan untuk semakin tipis, serta konteks komunikasi berlangsung dalam dunia maya atau virtual. Arus pesan dalam media virtual tidak bersifat linear atau one way saja namun berbentuk interaktif pada semua fasilitas yang disediakan. Interaktif disini bersifat penuh (fully interactive). Ini berarti bahwa semua pesan dalam media virtual mampu membuat respon (feedback) seketika bagi penerima pesan (pengguna). Respon atau feedback dalam bentuk pesan yang disampaikan oleh penerima pesan bentuknya tidak sevariatif pesan yang diterima (teks, grafis, audio, atau gambar) namun hanya sebatas teks atau audio saja (Sosiawan, 2001).

\section{Laman Penggemar di Facebook (Facebook Fan Page)}

Facebook merupakan situs social network/social media terpopuler di dunia pada dewasa ini. Dirilis pada Februari 2004 oleh seorang mahasiswa Harvard University bernama Mark Zuckerberg. Tujuan awal pengembangan Facebook ini yaitu hanya sebagai media untuk saling mengenal antar mahasiswa Harvard tanpa harus bertatap muka langsung. Kini, Facebook memiliki hampir 400 juta pengguna di seluruh dunia. Facebook sebagai situs pertemanan menyediakan jasa berbagi data, foto, link (tautan), video dan lainnya yang lebih komprehensif dan lebih praktis jika dibandingkan social media lainnya. Facebook juga mengandalkan fitur yang apik dan menarik seperti update status, e-mail dan chat, informasi aktivitas yang interaktif dan mudah diikuti yaitu dalam bentuk wall, hingga fasilitas upload foto yang dilengkapi sistem tagging untuk menandai orang yang kita kenal membuat para pengguna asyik menghabiskan waktu menggunakan situs social networking satu ini. Terobosan fitur lainnya adalah Facebook Application. Facebook menyediakan API (Application Programming Interface) dan juga script FBML yang memungkinkan para programmer membuat aplikasi-aplikasi web yang bisa diintegrasikan dengan Facebook.

Lalu, salah satu fasilitas yang kemudian ditawarkan oleh Facebook yaitu LPF (Laman Penggemar Facebook/Facebook Fan Page). LPF menurut Mardianto (2010) adalah profil sebuah lembaga. Lembaga di sini dapat berarti band, merek, perusahaan, website, dan sebagainya. LPF dapat memungkinkan lembaga yang terkait memiliki penggemar (dalam LPF disebut fans) tanpa menunggu persetujuan pengelola LPF. Oleh karena itu, LPF lebih bersifat publik atau terbuka jika dibandingkan dengan grup (group) di Facebook. LPF juga dapat memiliki keanggotaan hingga 5000 fans sehingga relatif cocok untuk band, merek, website, atau perusahaan dengan publik/massa yang besar.

\section{Konsep Agriwisata}

Agrowisata menurut Tirtawinata dan Fachruddin (1999), adalah rangkaian aktivitas perjalanan wisata yang memanfaatkan lokasi atau kawasan dan sektor pertanian mulai dari awal sampai dengan produk pertanian dalam berbagai sistem, skala dan bentuk dengan tujuan untuk memperluas pengetahuan, pemahaman, pengalaman dan rekreasi di bidang pertanian ini. Menurut Surat Keputusan Bersama (SK Bersama) Menteri Pariwisata, Pos dan Telekomunikasi dengan Menteri Pertanian yang dituangkan dalam SK Bersama No. KM 47/PW.DVM/MPPT.88 dan No. 204/KPTS/MK.050/4/1989, agrowisata diartikan sebagai suatu bentuk kegiatan yang memanfaatkan usaha agro sebagai obyek wisata dengan tujuan untuk memperluas pengetahuan, pengalaman, rekreasi, dan hubungan usaha di bidang pertanian. Sajian yang diberikan kepada wisatawan tidak hanya pemandangan kawasan pertanian yang panoramik dan kenyamanan di alam pertanian, tetapi juga aktivitas petani beserta teknologi khas yang digunakan dan dilakukan dalam lahan pertanian dimana wisatawan juga dapat mengikuti aktivitas ini, ketersediaan produk segar pertanian yang dapat dinikmati wisatawan, nilai historik lokasi, arsitektur, atau kegiatan tertentu, budaya pertanian yang khas dan kombinasi dari berbagai ciri tersebut. Lebih lanjut, Tirtawinata dan Fachruddin (1999) menambahkan agrowisata juga dapat memberikan manfaat sebagai berikut: (1) meningkatkan konversi lingkungan, (2) meningkatkan nilai estetika, (3) memberikan nilai rekreasi, (4) meningkatkan kegiatan ilmiah dan pengembangan ilmu pengetahuan, dan (5) mendapatkan keuntungan ekonomi.

\section{Kerangka Pemikiran}

Berdasarkan studi literatur yang sebelumnya telah dilakukan, karakteristik publik sasaran seperti usia, jenis kelamin, tingkat pendapatan dan tingkat pendidikan 
diduga merupakan aspek yang berhubungan dengan efektivitas strategi pencitraan tersebut. Karakteristik publik sasaran kemudian dapat mewakili unsur 'receiver' atau penerima dalam model komunikasi Berlo (1960). Keefektifan strategi pencitraan yang dilakukan oleh PR ditentukan oleh citra perusahaan yang terbentuk pada publik sasarannya dapat dilihat sebagai 'effect' dari sebuah proses komunikasi yang terjadi. Variabel lainnya yang juga mempengaruhi efektivitas yaitu kredibilitas perusahaan. Dalam model komunikasi Berlo (1960), kredibilitas perusahaan dapat mewakili unsur 'Source' atau sumber pesan. Citra perusahaan kemudian dapat dilihat dari sikap publik sasaran terhadap perusahaan. Untuk dapat melihat sikap publik sasaran, dapat diketahui dari tiga aspek pembentuknya yaitu: kognisi (pengertian atau nalar), afeksi (perasaan atau emosi), dan konasi (tingkah laku). Semakin positif sikap publik sasaran terhadap perusahaan maka semakin positif pula citra perusahaan tersebut. Hal ini didukung oleh Ruslan (2008) yang menyatakan bahwa aktivitas PR yang menyangkut pendapat umum (opini publik) merupakan aspek yang penting untuk keberhasilan menciptakan opini publik positif dan pada akhirnya tercipta citra yang baik bagi suatu organisasi maupun perusahaan. Ruslan (2008) kemudian menambahkan bahwa faktor-faktor yang membentuk opini publik, yaitu dipengaruhinya oleh komponen cognition/kognisi (pemahaman atau nalar), affect/afeksi (perasaan atau emosi), dan behavior/konasi (kecenderungan bertingkah laku), dan berikut adalah bagan kerangka pemikiran tersebut.

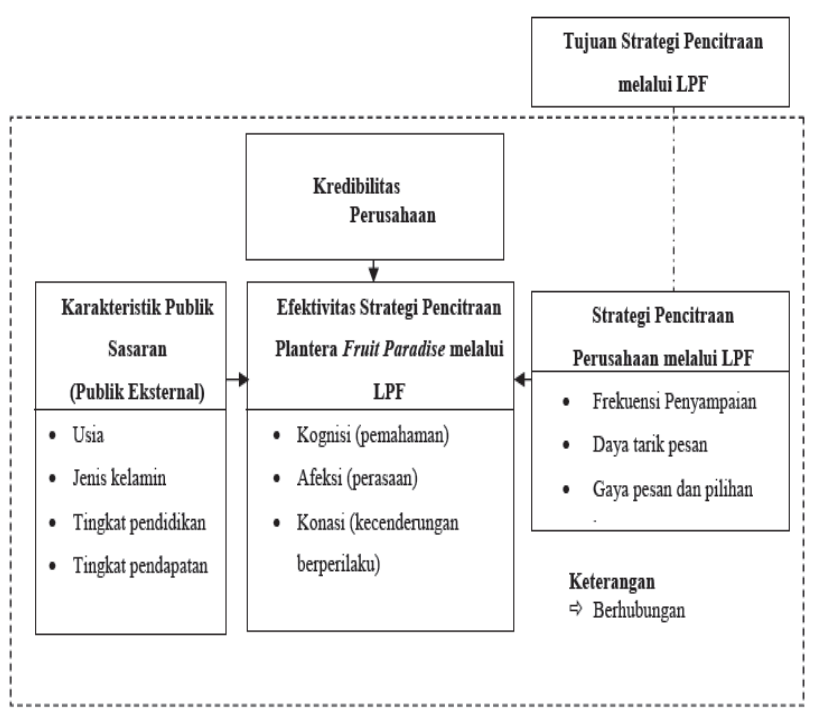

\section{Hipotesis Penelitian}

Berdasarkan kerangka pemikiran, hipotesis uji (Hk atau Ha) dalam penelitian ini adalah strategi pencitraan melalui LPF efektif dalam meningkatkan pemahaman, perasaan suka terhadap Plantera Fruit Paradise dan meningkatkan kecenderungan publik untuk mengunjungi Plantera.

\section{PENDEKATAN LAPANGAN}

\section{Alasan Pemilihan Metode}

Penelitian ini menggunakan metode kuantitatif dan didukung oleh data kualitatif. Pendekatan kuantitatif dilakukan dengan menggunakan metode survei, yaitu wawancara dengan menggunakan kuesioner, untuk kemudian seluruh jawaban yang diperoleh peneliti dicatat, diolah, dan dianalisis (Prasetyo dan Jannah, 2005). Data kualitatif didapatkan dengan melakukan wawancara mendalam untuk mengetahui lebih dalam mengenai strategi pencitraan, tujuan strategi pencitraan, visi dan misi serta profil perusahaan. Data dalam penelitian ini dibagi ke dalam dua jenis, yaitu data primer dan data sekunder. Data primer merupakan data yang diperoleh langsung oleh peneliti dari hasil kuesioner, wawancara, maupun hasil pengamatan. Sementara itu data sekunder diperoleh dari sumber-sumber sekunder, seperti company profile, data-data dokumentasi atau sumber pustaka lainnya.

\section{Lokasi dan Waktu Penelitian}

Lokasi tempat penelitian akan dilaksanakan di kebun Ngebruk (lokasi Plantera Fruit Paradise), Desa Sidokumpul, Patean, Kabupaten Kendal, Jawa Tengah dan kantor pusat PT. Cengkeh Zanzibar dan PT. Plantera di Jalan Imam Bonjol 155, Semarang. Pemilihan lokasi dilakukan dengan sengaja (purposive) dengan pertimbangan, yaitu: (1) lokasi penelitian sesuai dengan permasalahan yang akan diteliti oleh peneliti, (2) kebun buah Plantera Fruit Paradise merupakan kebun buah terbesar pertama di Jawa Tengah dan saat ini tengah gencarnya melakukan promosi, dan (3) Plantera memiliki LPF dan surat elektronik (e-mail), sehingga memudahkan peneliti dalam mengakses informasi yang aktual dan faktual mengenai Plantera serta melakukan penelitian mengenai keefektifan LPF tersebut. Dengan pertimbangan tersebut diharapkan dapat diamati efektivitas dan bentuk implementasi strategi pencitraan yang dilakukan Plantera. Data-data penelitian dikumpulkan sejak Juni 2010 hingga Juli 2010. Penetapan waktu tersebut tidak mutlak dan bersifat fleksibel. Penelitian diawali dengan studi penjajagan yang dilakukan awal bulan Mei 2010.

\section{Teknik Pengumpulan Data}

Populasi dari penelitian ini adalah publik sasaran Plantera khususnya publik eksternalnya. Seluruh responden diharuskan memenuhi persyaratan minimal yaitu memiliki akun Facebook dan minimal sekali pernah mengunjungi LPF Plantera Fruit Paradise, serta kemudian mengunjungi Plantera Fruit Paradise. Metode penelitian yang digunakan adalah non-probability sampling. Metode ini dipilih karena semua anggota populasi tidak memiliki kesempatan yang sama untuk menjadi responden (Simamora, 2004). Selain itu, teknik ini dipilih karena sampling frame (kerangka sampel) yang menjadi dasar pengambilan sampel tidak tersedia atau tidak lengkap. Teknik non-probability sampling yang digunakan adalah accidental sampling. Teknik ini menurut Mustafa (2000), merupakan teknik memilih sampel yang sedang berada di lokasi penelitian pada saat penelitian dilakukan (man oin the street). Unit-unit analisis kemudian digolongkan ke dalam gugus-gugus (clusters) sesuai hari kunjungan. Hanya terdapat dua gugus besar yaitu hari kerja dan hari libur yang dianggap telah dapat memenuhi syarat keragaman data. Diantara lima hari kerja dipilih hari kunjungan rabu dikarenakan persyaratan dari tempat penelitian yang hanya membolehkan penelitian dilakukan pada hari tersebut. 
Kemudian untuk mewakili hari libur dipilih responden yang berkunjung pada hari kunjungan sabtu atau minggu. Sementara informan untuk penelitian ini adalah seluruh karyawan PT. Plantera yang menangani promosi Plantera Fruit Paradise dan terutama admin atau pengelola LPF Plantera. Informan yang berasal dari pengunjung dipilih dengan menggunakan prinsip purposive (sengaja), sedangkan informan dari perusahaan dipilih secara snowball sampling (prinsip bola salju).

Penelitian ini memiliki sejumlah keterbatasan. Pertama, lokasi penelitian adalah lokasi obyek wisata dan subyek penelitian bukanlah pengunjung/wisatawan yang rutin atau tetap berkunjung ke lokasi penelitian setiap harinya sehingga peneliti tidak dapat menerapkan sistem pengundian dalam menentukan responden penelitian. Kedua, otoritas perusahaan tempat penelitian mensyaratkan peneliti hanya dapat melakukan kegiatan penelitian pada hari sabtu/minggu dan hari rabu. Hal ini menyebabkan data kurang beragam pada hari kunjungan hari kerja dan berada di luar kuasa peneliti sehingga penelitian dapat berkurang kemurniannya. Ketiga, persyaratan minimal yaitu memiliki akun Facebook, pernah sekali mengunjungi LPF Plantera Fruit Paradise Ngebruk, dan kemudian mengunjungi Plantera Fruit Paradise ternyata merupakan persyaratan yang hanya dapat dipenuhi sejumlah kecil responden. Hal tersebut ditambah dengan persyaratan waktu penelitian yang kurang dari cukup sehingga peneliti kemudian memutuskan hanya mengambil 20 responden yang berkunjung pada hari kerja dan 20 responden yang berkunjung pada hari libur. Jumlah tersebut ditentukan berdasarkan pengamatan peneliti pada kecenderungan jumlah kunjungan responden yang dapat memenuhi persyaratan yang telah disebutkan di atas.

\section{Teknik Pengolahan dan Analisis Data}

Data kualitatif yang telah diperoleh akan dianalisis secara kualitatif dengan cara mendeskripsikan dan menginterpretasikan fenomena yang ada di lapangan. Data kuantitatif yang berupa data primer diolah, ditabulasikan dan kemudian disajikan dalam bentuk tabel frekuensi dan tabulasi silang. Selanjutnya data kuantitatif kemudian mendapatkan perlakuan pengujian dengan menggunakan uji korelasi Rank Spearman untuk data ordinal dan mengetahui hubungan antar variabel yang diinginkan dan uji Chi Square untuk mengukur korelasi antar dua variabel yang memiliki tingkat pengukuran nominal-ordinal. Kriteria pengujian pada uji Rank Spearman adalah $\mathrm{H} 0$ gagal ditolak jika $\mathrm{P}$ value $>0,05$ dan H0 ditolak jika $\mathrm{P}$ value < 0,05 (Priyatno, 2008). Kriteria pengujian pada uji Kai Kuadrat adalah $\mathrm{H} 0$ ditolak apabila nilai $\mathrm{X}^{2}$ hitung $>\mathrm{X}^{2}$ tabel dan $\mathrm{H} 0$ gagal ditolak apabila nilai $X^{2}$ hitung $<X^{2}$ tabel (Priyatno, 2008). Uji korelasi dilakukan dengan bantuan perangkat lunak statistika yaitu SPSS 17.0 for Windows. Data hasil analisis statistik yang telah didapatkan kemudian diberikan makna melalui bantuan informasi dari informan.

\section{KARAKTERISTIK RESPONDEN}

\section{Jenis Kelamin}

Penelitian ini dilakukan terhadap 20 orang responden pada hari kerja (responden hari kerja) dan 20 orang responden pada hari libur (responden hari libur). Responden hari kerja didominasi oleh perempuan sebanyak 55 persen dan laki-laki sebanyak 45 persen. Hal ini hampir tidak jauh berbeda dengan responden hari libur yaitu, perempuan dan laki-laki berbanding jumlah yang sama (50 persen). Hal ini disebabkan kegiatan berwisata seperti berkunjung ke kebun buah menurut pandangan masyarakat sekitar adalah kegiatan keluarga, kegiatan bersama relasi atau orang-orang terdekat dan tidak dibatasi oleh jenis kelamin sehingga siapa saja dapat berkunjung ke Plantera Fruit Paradise.

\section{Usia}

Responden pada hari libur sebagian besar (45 persen) termasuk ke dalam kategori dewasa sedang (usia 31 sampai 50 tahun. Persentase data responden menurut kelompok usia dan hari kunjungan dapat dilihat pada Tabel 1 dan Tabel 2.

Tabel 1. Persentase Responden Hari Kerja menurut Usia, Plantera Fruit Paradise Ngebruk, 2010.

\begin{tabular}{llcr}
\hline Usia & Kategori & Jumlah & Persentase \\
\hline $18-30$ & Dewasa Awal & 3 & 15,00 \\
$31-50$ & Dewasa sedang & 9 & 45,00 \\
$>50$ & Dewasa Tua & 8 & 40,00 \\
\hline Total & & 20 & 100,00 \\
\hline
\end{tabular}

Responden yang berkunjung pada hari kerja sebagian besar (45 persen) berusia antara 31-50 tahun (dewasa sedang).

Tabel 2. Persentase Responden Hari Libur menurut Usia, Plantera Fruit Paradise Ngebruk, 2010.

\begin{tabular}{llcc}
\hline Usia & Kategori & Jumlah & \multicolumn{1}{c}{ Persentase } \\
\hline $18-$ & Dewasa Awal & 6 & 30,00 \\
30 & Dewasa Sedang & 10 & 50,00 \\
$31-$ & 4 & 20,00 \\
50 & Dewasa Tua & 20 & 100,00 \\
\hline 50 & & 20
\end{tabular}

Responden pada hari libur sebagian besar ( 50 persen) berusia antara 31-50 tahun (dewasa sedang). Hal ini disebabkan pada hari libur pengunjung lebih beragam daripada hari kerja. Responden berusia dewasa muda yang bersekolah atau kuliah pada hari kerja dapat berkunjung ke Plantera Fruit Paradise pada hari libur sehingga kecenderungan responden berusia dewasa sedang dan dewasa muda lebih banyak daripada pada hari kerja.

\section{Tingkat Pendidikan}

Jumlah dan persentase responden menurut tingkat pendidikan dan hari kunjungan dapat dilihat pada Tabel 3 dan Tabel 4. 
Tabel 3. Persentase Responden Hari Kerja menurut Tingkat Pendidikan, Plantera Fruit Paradise Ngebruk, 2010 .

\begin{tabular}{llcr}
\hline $\begin{array}{l}\text { Tingkat } \\
\text { Pendidikan }\end{array}$ & Kategori & Jumlah & Persentase \\
\hline $\begin{array}{l}\text { Tamat/tidak } \\
\text { tamat SD atau } \\
\text { sederajat }\end{array}$ & Rendah & 1 & 5,00 \\
$\begin{array}{l}\text { SLTP dan SLTA } \\
\text { atau sederajat }\end{array}$ & Sedang & 7 & 35,00 \\
$\begin{array}{l}\text { Pernah } \\
\text { mengenyam } \\
\text { pendidikan di } \\
\text { perguruan tinggi }\end{array}$ & Tinggi & 12 & 60,00 \\
\hline $\begin{array}{l}\text { Total } \\
\text { Bendasakan Tabel }\end{array}$ & & 20 & 100,00
\end{tabular}

Berdasarkan Tabel 3, dapat diketahui bahwa sebagian besar responden bertingkat pendidikan tinggi yaitu setidaknya pernah sekali mengenyam pendidikan formal di perguruan tinggi. Diperoleh juga informasi bahwa pendidikan tertinggi dari responden hari kerja adalah S2. Berdasarkan informasi dari buku tamu, pengunjung Plantera Fruit Paradise pada hari kerja didominasi responden yang berprofesi sebagai karyawan perusahaan sehingga tingkat pendidikan cenderung termasuk tinggi.

Tabel 4. Persentase Responden Hari Libur menurut Tingkat Pendidikan, Plantera Fruit Paradise Ngebruk, 2010.

\begin{tabular}{llcr}
\hline $\begin{array}{l}\text { Tingkat } \\
\text { Pendidikan }\end{array}$ & Kategori & Jumlah & Persentase \\
\hline $\begin{array}{l}\text { Tamat/tidak } \\
\text { tamat SD atau } \\
\text { sederajat }\end{array}$ & Rendah & 5 & 25,00 \\
$\begin{array}{l}\text { SLTP dan SLTA } \\
\text { atau sederajat }\end{array}$ & Sedang & 9 & 45,00 \\
$\begin{array}{l}\text { Pernah } \\
\text { mengenyam } \\
\text { pendidikan di } \\
\text { perguruan tinggi }\end{array}$ & Tinggi & 6 & 30,00 \\
\hline Total & & 20 & 100,00
\end{tabular}

Pada Tabel 4, didapatkan informasi bahwa pada hari libur, responden lebih beragam sehingga responden tidak lagi berkategori bertingkat pendidikan tinggi seperti pada hari kerja. Responden hari libur lebih banyak merupakan responden yang bertingkat pendidikan sedang atau tingkat pendidikannya SLTP/SMA sederajat.

\section{Tingkat Pendapatan}

Tingkat pendapatan dalam penelitian ini diukur dari jumlah penghasilan seseorang tiap bulannya. Persentase responden berdasarkan tingkat pendapatan rata-rata per bulan dan hari kunjungan dapat dilihat pada Tabel 5.

Tabel 5. Persentase Responden Hari Kerja berdasarkan Pendapatan per Bulan, Plantera Fruit Paradise Ngebruk, 2010.

\begin{tabular}{lccc}
\hline Tingkat & Kategori & Jumlah & Persentase \\
\hline $\begin{array}{l}\text { Pendapatan } \\
\text { Rp }\end{array}$ Rendah & 4 & $20,000,00$ \\
$>\mathrm{Rp}$ & Ren & & \\
$1.939 .000,00$ & Tinggi & 16 & 80,00 \\
\hline Total & & 20 & 100,00 \\
\hline
\end{tabular}

Pengkategorian tingkat pendapatan pada penelitian ini dilakukan berdasarkan rata-rata pendapatan yang sesuai dengan yang didapatkan di lapangan. Tampak pada Tabel 5 , responden yang melakukan kunjungan pada hari kerja cenderung bertingkat pendapatan tinggi. Hal ini berkaitan dengan penjelasan sebelumnya bahwa responden yang berkunjung pada hari kerja merupakan karyawankaryawan di sebuah perusahaan yang memiliki pendapatan cukup tinggi. Lain hal yang terjadi pada responden hari libur yang disajikan dalam Tabel 6 berikut.

Tabel 6. Persentase Responden Hari Libur berdasarkan Pendapatan per Bulan, Plantera Fruit Paradise Ngebruk, 2010.

\begin{tabular}{lccc}
\hline Tingkat & Kategori & Jumlah & \multicolumn{1}{l}{ Persentase } \\
\hline $\begin{array}{l}\text { Pendapatan } \\
\text { Rp }\end{array}$ & Rendah & 11 & 55,00 \\
$\begin{array}{l}1.939 .000,00 \\
\text { Rp }\end{array}$ & Tinggi & 9 & 45,00 \\
$1.939 .000,00$ & & 20 & 100,00 \\
\hline Total & & 20
\end{tabular}

Berdasarkan Tabel 6, responden pada kunjungan hari libur lebih beragam sehingga cukup banyak responden yang tergolong dalam bertingkat pendapatan rendah atau tidak lebih dari Rp 1.939.000,00 per bulannya.

\section{EFEKTIVITAS STRATEGI PENCITRAAN PLANTERA FRUIT PARADISE MELALUI LPF}

\section{Aspek Kognisi}

Aspek kognisi adalah pengetahuan publik sasaran tentang kebun buah Plantera. Aspek kognisi yang diteliti meliputi pengetahuan mengenai jenis usaha yang dilakukan Plantera, produk Plantera, alamat Plantera, dan fasilitas yang dimiliki Plantera. Responden lalu diberikan sepuluh pernyataan yang berkaitan dengan pengetahuan mengenai kebun buah Plantera tersebut. Aspek kognisi kemudian diukur dengan menjumlahkan skor dari hasil jawaban responden dan dimasukkan dalam dua kategori, yaitu rendah dan tinggi. Aspek kognisi mengenai perusahaan pada responden hari kerja disajikan pada Tabel 11.

Tabel 11 Persentase Responden Hari Kerja berdasarkan Aspek Kognisi mengenai Perusahaan, Plantera Fruit Paradise Ngebruk, 2010.

\begin{tabular}{lcc}
\hline Kategori & Jumlah & Persentase \\
\hline Rendah & 9 & 45,00 \\
Tinggi & 11 & 55,00 \\
\hline Total & 20 & 100,00 \\
\hline
\end{tabular}


Berdasarkan hasil penelitian, aspek kognisi pada responden hari kerja menunjukan hasil yang tinggi. Hal ini menunjukan tingkat pengetahuan yang baik mengenai Plantera Fruit Paradise. Terbukti bahwa mayoritas responden mengetahui bahwa Plantera Fruit Paradise merupakan kebun buah terbesar di Jawa Tengah yang menyediakan buah-buahan tropis dan terletak di Kebun Ngebruk, Desa Sidokumpul, Patean, Kabupaten Kendal. Kemudian, aspek kognisi mengenai perusahaan pada responden hari libur ditampilkan pada Tabel 12.

Tabel 12 Persentase Responden Hari Libur berdasarkan Aspek Kognisi mengenai Perusahaan, Plantera Fruit Paradise Ngebruk, 2010.

\begin{tabular}{lcc}
\hline Kategori & Jumlah & Persentase \\
\hline Rendah & 12 & 60,00 \\
Tinggi & 8 & 40,00 \\
\hline Total & 20 & 100,00
\end{tabular}

Berbeda dengan hasil pada responden hari kerja yang ditunjukkan pada Tabel 11, responden hari libur (Tabel 12) menunjukkan hasil aspek kognisi yang cenderung rendah. Responden hari libur memiliki tingkat pengetahuan yang tidak begitu baik mengenai Plantera Fruit Paradise. Beberapa responden yang menjawab benar pada pertanyaan mengenai letak kebun buah Plantera tetapi juga menjawab salah mengenai letak Plantera berikutnya yaitu menjawab Plantera Fruit Paradise dekat dengan pusat kota Semarang, Simpanglima.

Berdasarkan pengamatan, pada responden hari libur, responden datang bersama keluarga dan sejumlah responden cenderung terburu-buru mengisi kuesioner agar bisa segera bergabung dengan anggota keluarga yang lain untuk berwisata sehingga responden kurang cermat dalam menjawab. Hal ini berbeda dengan responden hari kerja, jumlah kunjungan tidak terlalu banyak sehingga responden memiliki waktu banyak dalam menjawab kuesioner sehingga lebih teliti dalam menjawab pertanyaan dalam kuesioner.

\section{Aspek Afeksi}

Aspek afeksi adalah perasaan responden dalam menanggapi hal-hal tentang kebun buah Plantera. Responden diberikan sepuluh pernyataan yang berkaitan dengan perasaan responden mengenai Plantera Fruit Paradise. Aspek afeksi yang ditanyakan berkaitan dengan perasaan suka, perasaan nyaman, perasaan aman, merasakan keramahan, dan ketertiban menurut responden terhadap Plantera. Aspek afeksi kemudian diukur dengan menjumlahkan skor dari hasil jawaban responden dan dimasukkan dalam dua kategori, yaitu rendah dan tinggi. Aspek afekitif mengenai perusahaan pada responden hari kerja disajikan pada Tabel 13.
Tabel 13Persentase Responden Hari Kerja berdasarkan Aspek Afeksi mengenai Perusahaan, Plantera Fruit Paradise Ngebruk, 2010.

\begin{tabular}{lcr}
\hline Kategori & Jumlah & Persentase \\
\hline Buruk & 8 & 40,00 \\
Baik & 12 & 60,00 \\
\hline Total & 20 & 100,00 \\
\hline
\end{tabular}

Berdasarkan Tabel 13, responden menunjukkan afeksi yang tinggi pada Plantera Fruit Paradise. Responden menyukai Plantera sebagai tempat wisata yang baik. Responden juga merasa Plantera Fruit Paradise adalah tempat yang aman, sejuk, dan ramah dalam pelayanannya. Kemudian, aspek afeksi mengenai perusahaan pada responden hari libur ditampilkan pada Tabel 14.

Tabel 14 Persentase Responden Hari Libur berdasarkan Aspek Afeksi mengenai Perusahaan, Plantera Fruit Paradise Ngebruk, 2010.

\begin{tabular}{lcr}
\hline Kategori & Jumlah & Persentase \\
\hline Buruk & 4 & 20,00 \\
Baik & 16 & 80,00 \\
\hline Total & 20 & 100,00 \\
\hline Seperti halnya hasil penelitian pada responden hari kerja
\end{tabular}

Seperti halnya hasil penelitian pada responden hari kerja, responden hari libur menunjukkan hasil yang tinggi pada aspek afeksi. Responden pada hari libur juga merasa Plantera Fruit Paradise adalah tempat yang nyaman dan tidak panas. Responden juga menyukai kunjungan mereka ke Plantera Fruit Paradise.

\section{Aspek Konasi}

Aspek konasi adalah kecenderungan berbuat terhadap kebun buah Plantera. Responden diberikan sepuluh pernyataan tentang kecenderungan bertindak responden terhadap Plantera Fruit Paradise. Sepuluh pernyataan tersebut antara lain berkaitan keinginan untuk melakukan kunjungan kembali ke kebun, keinginan mencoba atau membeli produk Plantera yang lainnya, dan keinginan melakukan aktivitas lain di Plantera. Aspek konasi diukur dengan menjumlahkan skor dari hasil jawaban responden dan dimasukkan dalam dua kategori, yaitu rendah dan tinggi. Aspek konasi mengenai perusahaan pada responden hari kerja disajikan pada Tabel 15. 
Tabel 15 Persentase Responden Hari Kerja berdasarkan Aspek Konasi mengenai Perusahaan, Plantera Fruit Paradise Ngebruk, 2010.

\begin{tabular}{lcr}
\hline Kategori & Jumlah & Persentase \\
\hline Rendah & 7 & 35,00 \\
Tinggi & 13 & 65,00 \\
\hline Total & 20 & 100,00
\end{tabular}

Berdasarkan hasil penelitian pada aspek konasi, responden hari kerja menunjukan hasil yang tinggi. Hal ini menunjukkan kecenderungan berbuat terhadap Plantera Fruit Paradise yang baik. Sejumlah responden ingin mengunjungi Plantera bersama anggota keluarga yang lain atau relasi lainnya pada kunjungan berikutnya. Responden juga ingin menikmati buah-buahan tropis lainnya di musim berikutnya. Kemudian, aspek konasi mengenai perusahaan pada responden hari libur ditampilkan pada Tabel 16.

Tabel 16 Persentase Responden Hari Libur berdasarkan Aspek Konasi mengenai Perusahaan, Plantera Fruit Paradise Ngebruk, 2010.

\begin{tabular}{lcr}
\hline Kategori & Jumlah & Persentase \\
\hline Rendah & 6 & 30,00 \\
Tinggi & 14 & 70,00 \\
\hline Total & 20 & 100,00
\end{tabular}

Pada responden hari libur, hasil penelitian aspek konasi mengenai perusahaan juga menunjukkan hasil yang tinggi. Responden ingin mencoba paket wisata lainnya yang ditawarkan Plantera Fruit Paradise. Responden pada hari libur juga ingin datang kembali ke kebun buah Plantera bersama anggota keluarga lainnya atau bersama teman lainnya seperti halnya yang terjadi pada kelompok responden hari kerja.

Berdasarkan hasil yang ditunjukkan oleh data di lapangan strategi pencitraan Plantera Fruit Paradise melalui LPF secara menyeluruh menunjukkan hasil yang positif yaitu efektif dalam penerapannya. Responden menunjukkan hasil yang positif dalam pengetahuan (kognisi), perasaan (afeksi), dan kecenderungan berperilaku (konasi) terhadap Plantera Fruit Paradise sehingga dapat dikatakan strategi pencitraan Plantera Fruit Paradise melalui LPF berjalan efektif terhadap publik eksternalnya.

\section{HUBUNGAN ANTARA KARAKTERISTIK PUBLIK SASARAN DENGAN EFEKTIVITAS STRATEGI PENCITRAAN MELALUI LPF}

Variabel jenis kelamin tidak berhubungan nyata dengan variabel efektivitas strategi pencitraan melalui LPF pada kedua kelompok responden baik hari kerja maupun hari libur. Artinya, pemahaman, perasaan suka terhadap Plantera, dan kecenderungan untuk mengunjungi Plantera pada tiap jenis kelamin (laki-laki atau perempuan) adalah sama.

Matrik 1. Hubungan Antara Karakteristik Jenis Kelamin dengan Efektivitas Pencitraan dari Aspek Perubahan Perilaku, Plantera Fruit Paradise Ngebruk, 2010

\begin{tabular}{lcl}
\hline $\begin{array}{c}\text { Aspek } \\
\text { perilaku }\end{array}$ & $\begin{array}{r}\text { Responden } \\
\text { Hari } \\
\text { Kerja }\end{array}$ & \multicolumn{1}{c}{$\begin{array}{c}\text { Responden Hari } \\
\text { Libur }\end{array}$} \\
\hline Kognisi & Tidak nyata & Tidak nyata \\
Afeksi & Tidak nyata & Tidak nyata \\
Konasi & Tidak nyata & Tidak nyata \\
\hline
\end{tabular}

Variabel usia publik sasaran pada kedua kelompok responden berhubungan dengan variabel efektivitas strategi pencitraan melalui LPF. Artinya, pada tiap jenjang usia, pemahaman, perasaan suka terhadap Plantera, dan kecenderungan untuk mengunjungi Plantera ditemukan berbeda. Hubungan bersifat positif yang bermakna semakin tinggi usia responden maka semakin baik pula pemahaman mengenai Plantera, perasaan suka terhadap Plantera, dan kecenderungan responden untuk mengunjungi Plantera.

Matrik 2. Hubungan Antara Karakteristik Usia dengan Efektivitas Pencitraan dari Aspek Perubahan Perilaku, Plantera Fruit Paradise Ngebruk, 2010

\begin{tabular}{lrl}
\multicolumn{1}{c}{$\begin{array}{c}\text { Aspek } \\
\text { perilaku }\end{array}$} & $\begin{array}{r}\text { Responden } \\
\text { Hari } \\
\text { Kerja }\end{array}$ & $\begin{array}{c}\text { Responden Hari } \\
\text { Libur }\end{array}$ \\
\hline Kognisi & Sangat nyata & Sangat nyata \\
Afeksi & Sangat nyata & Sangat nyata \\
Konasi & Sangat nyata & Sangat nyata \\
\hline
\end{tabular}

Variabel tingkat pendidikan publik sasaran pada kedua kelompok responden berhubungan dengan variabel efektivitas strategi pencitraan melalui LPF. Artinya, pada tiap jenjang pendidikan, pemahaman, perasaan suka terhadap Plantera, dan kecenderungan responden mengunjungi Plantera ditemukan berbeda. Hubungan bersifat positif yang bermakna semakin tinggi tingkat pendidikan responden maka semakin baik pula pemahaman, perasaan suka, dan kecenderungan responden mengunjungi Plantera. 
Matrik 3. Hubungan Antara Karakteristik Tingkat Pendidikan dengan Efektivitas Pencitraan dari Aspek Perubahan Perilaku, Plantera Fruit Paradise Ngebruk, 2010

\begin{tabular}{lrl}
$\begin{array}{c}\text { Aspek } \\
\text { perilaku }\end{array}$ & $\begin{array}{r}\text { Responden } \\
\text { Hari } \\
\text { Kerja }\end{array}$ & $\begin{array}{r}\text { Responden } \\
\text { Hari Libur }\end{array}$ \\
\hline Kognisi & Sangat nyata & Sangat nyata \\
Afeksi & Sangat nyata & Sangat nyata \\
Konasi & Sangat nyata & Sangat nyata
\end{tabular}

Variabel tingkat pendapatan publik sasaran pada kedua kelompok responden berhubungan dengan variabel efektivitas strategi pencitraan melalui LPF. Artinya, pada tiap jenjang pendapatan, pemahaman, perasaan suka terhadap Plantera, dan kecenderungan responden mengunjungi Plantera ditemukan berbeda. Hubungan bersifat positif yang bermakna semakin tinggi tingkat pendapatan responden maka semakin baik pula pemahaman, perasaan suka, dan kecenderungan responden mengunjungi Plantera.

Matrik 4. Hubungan Antara Karakteristik Tingkat Pendapatan dengan Efektivitas Pencitraan dari Aspek Perubahan Perilaku, Plantera Fruit Paradise Ngebruk, 2010

\begin{tabular}{rrl}
$\begin{array}{c}\text { Aspek } \\
\text { perilaku }\end{array}$ & $\begin{array}{r}\text { Responden } \\
\text { Hari } \\
\text { Kerja }\end{array}$ & $\begin{array}{c}\text { Responden Hari } \\
\text { Libur }\end{array}$ \\
\hline Kognisi & Sangat nyata & Sangat nyata \\
Afeksi & Sangat nyata & Sangat nyata \\
Konasi & Sangat nyata & Sangat nyata \\
\hline
\end{tabular}

\section{KESIMPULAN DAN SARAN}

\section{Kesimpulan}

Strategi pencitraan Plantera Fruit Paradise melalui LPF telah cukup efektif dalam meningkatkan citra perusahaan agrowisata, artinya strategi tersebut telah berhasil meningkatkan pemahaman publik tentang Plantera, meningkatkan perasaan suka terhadap Plantera, serta mendorong responden untuk mengunjungi Plantera.

Semakin tua usia, semakin tinggi pendidikan, dan semakin tinggi tingkat pendapatan semakin baik tingkat pemahaman publik tentang Plantera, cenderung semakin menyukai Plantera, dan semakin terdorong untuk mengunjungi Plantera.

\section{Saran}

1. Apabila perusahaan ingin tetap meneruskan penggunaan LPF, maka perlu diadakan penambahan informasi di dalam LPF mengenai Plantera dan produkproduk yang ditawarkan perusahaan. Informasi mengenai rute menuju lokasi wisata, nomor yang dapat dihubungi dan foto-foto produk atau lokasi wajib dicantumkan di lokasi yang mudah ditemukan.
2. Promosi melalui LPF tersebut telah berpengaruh baik dan memperbaiki media promosi yang lemah telah dapat menjaring pengunjung lebih banyak dari sebelumnya, hendaknya tetap bisa berkelanjutan.

\section{DAFTAR PUSTAKA}

Ahmad, Asep. H. 2008. Analisis Teoritis Tentang Media Massa. http://ahmedleiza.blogspot.com/analisisteoritis/tentang-media-massa.html, diakses 20 Januari 2010, pukul 08:31 WIB.

Arnold, Benedictus. 2003. Peranan Hubungan Masyarakat dalam Era Informasi. Jurnal Ilmiah Universitas Pelita Harapan, Vol. VI, No.2, Agustus 2003. Lembaga Penelitian dan Pengabdian Kepada Masyarakat Universitas Pelita Harapan.

Berlo, 1960. The Process of Communication. An Introduction to Theory and Practice. New York: Holt, Rinehart and Winston, Inc.

Cutlip, Scott M, Allen H Center, Glen M. Broom. 2000. Effective Public Relations. Prentice Hall, Inc: New Jersey.

Hamidi. 2007. Metode Penelitian dan Teori Komunikasi: Pendekatan Praktis Penulisan Proposal dan Laporan Penelitian. Malang: UMM Press.

Haque, Ahsanul, Arun K. Tarofder, Shameem Al Mahmud. 2006. Internet Advertisement: Helps To Build Brand. International Islamic University Malaysia. Malaysia

Heryanto. 2009. Ruang Publik Komunitas Virtual. http://www.uinjkt.ac.id/index.php/section-blog/28artikel/117-ruang-publik-komunitas-virtual.html, diakses 10 Juni 2010 pukul 19.43 WIB.

Iriantara, Yosal. 2005. Media Relations: Konsep, Pendekatan, dan Praktik. Simbiosa Rekatama Media: Bandung.

Jahi, Amri. 1993. Media Cetak dan Pembangunan Perdesaaan di Negara-negara Dunia Ketiga. Dalam Komunikasi Massa dan Pembangunan di Negaranegara Dunia Ketiga: Suatu Pengantar (Editor Amri Jahi). Jakarta: PT Gramedia.

Joachimsthaler, Erich dan David A. Aaker. 1997. Building Brands without Mass Media. http://www.bus.iastate.edu/kpalan/mkt504/Joachims thaleraaker.pdf. diakses pada 04 November 2009, pukul 17.17 WIB

Lesly, Philip. 1991. Lesly’s Handbook of Public Relations and Communication. Probus Publishing Company: Chicago.

Mardianto, 2010. Perbedaan Grup dengan Halaman Fan Page Facebook. http://blog.mardianto.com/2010/02/-perbedaangrup-dengan-halaman-fan-page-Facebook/ diakses 18 Juni 2010 pukul 21.25 WIB.

Mulyana, Iman dan Dwi Suwandi. 2003. Citra Perusahaan. http://www.e- 
iman.uni.cc/citra_perusahaan.pdf diakses 04 November, pukul 16.59 WIB.

Muplihah, Laela. 2005. Strategi Public Relations dalam Membentuk Citra Perusahaan (Studi Kasus PT Syarikat Takaful Indonesia). Skripsi Sarjana (tak diterbitkan), Fakultas Pertanian Institut Pertanian Bogor, Bogor.

Mustafa. 2000. Accidental Sampling. http://www.osun.org/accidentalsampling diakses pada tanggal 20 November 2010, pukul 19.43 WIB.

Power, John. 2005. A Conceptual Model Of The Influence Of Brand Trust On Relationship Between Consumer And Company Image. http://eprints.wit.ie/468/1/a_conceptual_model_of_t he_influence_of_brand_trust_on_the_relationship_b etween_consumer_and_company_image_(2005).pdf diakses pada 04 November 2009, pukul 17.15 WIB.

Prasetyo, Bambang dan Lina Miftahul Jannah. 2005. Metode Penelitian Kuantitatif: Teori dan Aplikasi. Jakarta: PT. Raja Grafindo Persada.

Priyatno, Duwi. 2008. Mandiri Belajar SPSS. Yogyakarta: MediaKom.

Putri, Werda Andritya. 2005. Analisis Opini Publik Internal terhadap Pelaksanaan Fungsi dan Tugas Public Relations dalam Upaya Membangun Citra Perusahaan (Kasus Karyawan di Kantor Pusat PT Asuransi Takaful Umum, Mampang Prapatan, Jakarta Selatan). Skripsi Sarjana (tak diterbitkan), Fakultas Pertanian Institut Pertanian Bogor, Bogor.

Redjeki, Siti. 2003. Tanggapan Pelanggan Terhadap Citra PT. Telekomunikasi Indonesia Cabang Cicalengka Kabupaten Bandung. Tesis (tak diterbitkan), Fakultas Pertanian Institut Pertanian Bogor, Bogor.

Rozi, Zaenal A. 2009. Dasar Pengenalan tentang Internet. http://www.scribd.com/doc/19802347/Dasar-

Pengenalan-tentang-Internet. diakses pada 04 November 2009, pukul 17.22 WIB.

Rumanti, Maria Assumpta. 2002. Dasar-Dasar Public Relations: Teori dan Praktik. Penerbit PT Gramedia Widiasarana Indonesia: Jakarta.

Ruslan, Rosady. 2003. Kiat dan Strategi Kampanye Public Relations. Penerbit PT. Raja Grafindo Persada, Jakarta.

. 2008. Manajemen Public Relations\&Media Komunikasi (Konsep dan Aplikasi). Jakarta: Rajawali Press.

Sarwono, Sarlito Wirawan. 1999. Psikologi Sosial Individu dan Teori-Teori Psikologi Sosial. Jakarta: Balai Pustaka.

Simamora, B. 2004. Riset Pemasaran Falsafah, Teori dan Aplikasi. Jakarta: PT. Gramedia Pustaka Utama.

Singarimbun, Masri dan Sofian Effendi. 1995. Metode Penelitian Survei. LP3ES Indonesia: Jakarta.

Siregar, Ashadi. 2008. Hubungan Dengan Media: Strategi Publisitas

Korporasi. http://ashadisiregar.files.wordpress.com/2008/08/hu bungan-dengan-media-strategi-korporasi.pdf. diakses pada 04 November 2009, pukul 17.25 WIB.

Sosiawan, Edwi Arief. 2001. Kajian Internet Sebagai Media Komunikasi. Tesis (tak diterbitkan), PPS UNPAD, Bandung

Subagyo. 2007. Efektivitas Komunikasi Pembelajaran dengan Mode Distance Learning Berbasis Website. Tesis (tak diterbitkan), Fakultas Pertanian Institut Pertanian Bogor, Bogor.

Sugiah M., Siti. 2008. Modul Kuliah Pendidikan Orang Dewasa. Bogor

Sutoyo, Siswanto. 2004. Membangun Citra Perusahaan. Penerbit PT. Damar Mulia Pustaka, Jakarta.

Tirtawinata, M.R. dan L. Fachruddin. 1999. Daya Tarik dan Pengelolaan Agrowisata. Penebar Swadaya: Jakarta.

Wahyuni, E.S. 2004. Pedoman Teknis Menulis Skripsi. Penerbit Jurusan Ilmu-Ilmu Sosial Ekonomi Fakultas Pertanian, Institut Pertanian Bogor: Bogor. 